\section{Genetic Profiling of Red-Bracted Cornus kousa Cultivars Indicates Significant Cultivar Synonomy}

\author{
R.N. Trigiano, M.H. Ament, M.T. Windham, and J.K. Moulton \\ Department of Entomology and Plant Pathology, The University of Tennessee, \\ Knoxville, TN 37996-4560
}

Additional index words. arbitrary signatures from amplification profiles (ASAP), Cornus kousa, cultivar identification, DNA profiling, DNA amplification fingerprinting (DAF), flowering dogwood

Abstract. Cornus kousa Hance (Korean or kousa dogwood) cultivars are increasingly used as landscape plants because they lack the disease and insect problems typically associated with the native $C$. florida $\mathbf{L}$. (flowering dogwood). A number of red-bracted kousa dogwood cultivars are now available and several are phenotypically indistinguishable from one another. Plants of six cultivars obtained from three nurseries were characterized genetically using deoxyribonucleic acid (DNA) amplification fingerprinting (DAF) and arbitrary signatures from amplification profiles (ASAP). DAF profiles of three red-bracted cultivars-'Rosabella', ' Satomi' and 'Heart Throb'-were nearly identical. ASAP also failed to clearly differentiate these cultivars and indicated consistent genetic similarities. In contrast, another red-bracted cultivar 'Christian Prince' and two white-bracted cultivars-'Little Beauty' and 'Samaritan'-were identified and separated from all other cultivars by both DAF and ASAP techniques.

Cornus kousa Hance (Korean, Chinese, or kousa dogwood) cultivars are becoming more popular as landscape plants because they are generally resistant to many diseases (e.g., powdery mildew and dogwood anthracnose) that plague $C$. florida L. (flowering dogwood) (Hagan, et al., 1998; Ranney et al., 1995). The number of introduced kousa dogwood cultivars has increased dramatically in the last two decades (Dirr, 1998). These plants, which bloom $\approx 1$ month after flowering dogwood, are now available with either white, cream, pink, or red bracts. However, with rapid introduction of similar types of pink and red kousa dogwoods, there is an increased potential for mistakes in the trade, ranging from mislabeling and multiple release to misappropriation and misrepresentation.

A variety of red-bracted kousa dogwoods can be purchased through wholesale or retail nurseries. Although some of these cultivars are distinctive (i.e., variegated leaves), others appear quite similar or nearly identical. For example, 'Satomi' (synonym 'Miss Satomi') and 'Rosabella' have medium rose-pink bracts in cooler climates (blotchy pink in warmer) and share many vegetative characteristics and are considered to be the same cultivar (Dirr, 1998). 'Heart Throb' ('Schmred') has similar shoot attributes but has deep-red bracts and several Tennessee nurserymen have commented on the vegetative and reproductive similarities between 'Satomi' and 'Heart Throb' (Don Shadow, Shadow Nursery Inc., Winchester,

Received for publication 27 Nov. 2002. Accepted for publication 29 June 2003. We thank Willard Witte for the gifts of the Cornus kousa cultivars used in this study and the financial support of the Tennessee Agricultural Experiment Station and the USDA-ARS through award 58-6404-2-00057.
Tenn., personal communication). This project was undertaken to genetically examine four red-bracted C. kousa cultivars using two DNA (deoxyribonucleic acid) amplification profiling techniques and determine whether observed morphological similarities were coincidental, possibly due to mislabeling or repetitive release of the same or very similar material.

There are a number of arbitrarily primed PCR (polymerase chain reaction) techniques that can be used reliably to profile or characterize genomic DNA from closely related plants of many species and among these is DNA amplification fingerprinting (DAF) (Caetano-Anollés et al., 1991). DAF offers some advantages over other arbitrarily primed techniques such as randomly amplified polymorphic DNA (RAPD: Williams et al., 1990). Although both of these techniques amplify anonymous regions of DNA, DAF profiles are more robust revealing up to 40 scorable bands (700 base pairs or less in length) per primer compared to 7 to 12 bands typically visualized with the RAPD technique. Fewer primers and thus fewer reactions are needed to profile the plants of interest. A more complete comparison of these and other techniques may be found in Trigiano and Caetano-Anollés (1998) and Caetano-Anollés and Trigiano (1997).

Table 1. Sources of Cornus kousa cultivars.

\begin{tabular}{lll}
\hline Cultivar & Plant code & Source nursery \\
\hline 'Heart Throb' & H1-H5 & Shadow Nursery Inc., Winchester, Tennessee \\
& H6-H10 & Commercial Nursery Co., Decherd, Tennessee \\
& H11-H12 & Bush Nursery, Canby, Oregon \\
'Rosabella' & R1-R2 & Loen Nursery Inc., Sherwood, Oregon \\
'Satomi' & S1-S5 & Commercial Nursery Co., Decherd, Tennessee \\
& S6-S7 & Bush Nursery, Canby, Oregon \\
'Christian Prince' & PR2-PR3 & Commercial Nursery Co., Decherd, Tennessee \\
'Samaritan' & SA1-SA2 & Commercial Nursery Co., Decherd, Tennessee \\
'Little Beauty' & LB1-LB2 & Shadow Nursery Inc., Winchester, Tennessee \\
\hline
\end{tabular}
1:12 with sterile distilled water and used as template for the ASAP procedure. Mini-hairpin $(\mathrm{MH})$ primers were used in all ASAP reactions (Caetano-Anollés and Gresshoff, 1996). The following ASAP reactions were completed GCGAAGCGCA $(\mathrm{MH} 1) \times 8.6 \mathrm{~J}, \mathrm{GCGAAGC}$ GTT $(\mathrm{MH} 2) \times 8.6 \mathrm{~J}$, GCGAAGCCAT $(\mathrm{MH} 6) \times$ 8.6D and GCGAAGCTAT $(\mathrm{MH10}) \times 8.6 \mathrm{D}$.

Both DAF and ASAP amplification products were separated electrophoretically on 0.45 -mm-thick $10 \%$ acrylamide gels containing $7 \mathrm{M}$ urea (Trigiano and Caetano- Anollés, 1998). Amplification products were visualized using a fast and sensitive silver stain (Bassam et al., 1991). Amplification profiles (banding patterns in gels) were assessed on a light box and those bands of 700 base pairs or less were scored using binary code ( 1 or 0 ) to designate whether a band of a particular weight (base pairs) was present or absent, respectively. A question mark (?) was used to signify missing or questionable data. All binary data were entered as unordered, nondirected, and unweighted characters by primer and cultivar. Data were analyzed with the Numerical Taxonomy and Multivariate Analysis System (NTSYSpc) version 2.0 (Exeter Software, Setauket, N.Y.) ficients and then assembling dendrograms
Four red-bracted C. kousa cultivars, including 'Christian Prince' (PR), ' Rosabella' (R),, 'Heart Throb' (H), and 'Satomi' (S), and two white-bracted cultivars, 'Samaritan' (SA), which is variegated, and 'Little Beauty' (LB), were ordered from wholesale nurseries in Oregon and Tennessee (Table 1). At leas two plants of each cultivar were included in initial DNA characterization procedures. Later experiments only included multiple plants for cultivars ('Rosabella', 'Heart Throb', and 'Satomi') that demonstrated very similar or identical DNA profiles.

Young, not fully expanded leaves of each of the six cultivars were collected in early morning and stored at $-75^{\circ} \mathrm{C}$ until needed. Total DNA was extracted using a Puregene Kit (Gentra Systems, Minneapolis, Minn.). DAF was used to profile the genomic DNA of the cultivars. Reaction mixtures contained one of the following six primer sequences ( $\left.5^{\prime}-3^{\prime}\right)$ : GTATCGCC (8.6J), AATGCAGC (8.7A), GACGTAGG (8.6E), GTAACGCC (8.6D), TTCGTGCC (8.6O), and GTTACGCC (8.6I) Genomic DNA was also characterized using arbitrary signatures from amplification profiles (ASAP) (Caetano-Anollés and Gresshoff, 1996). DAF reaction products were diluted by first calculating Jaccard similarity coef- 


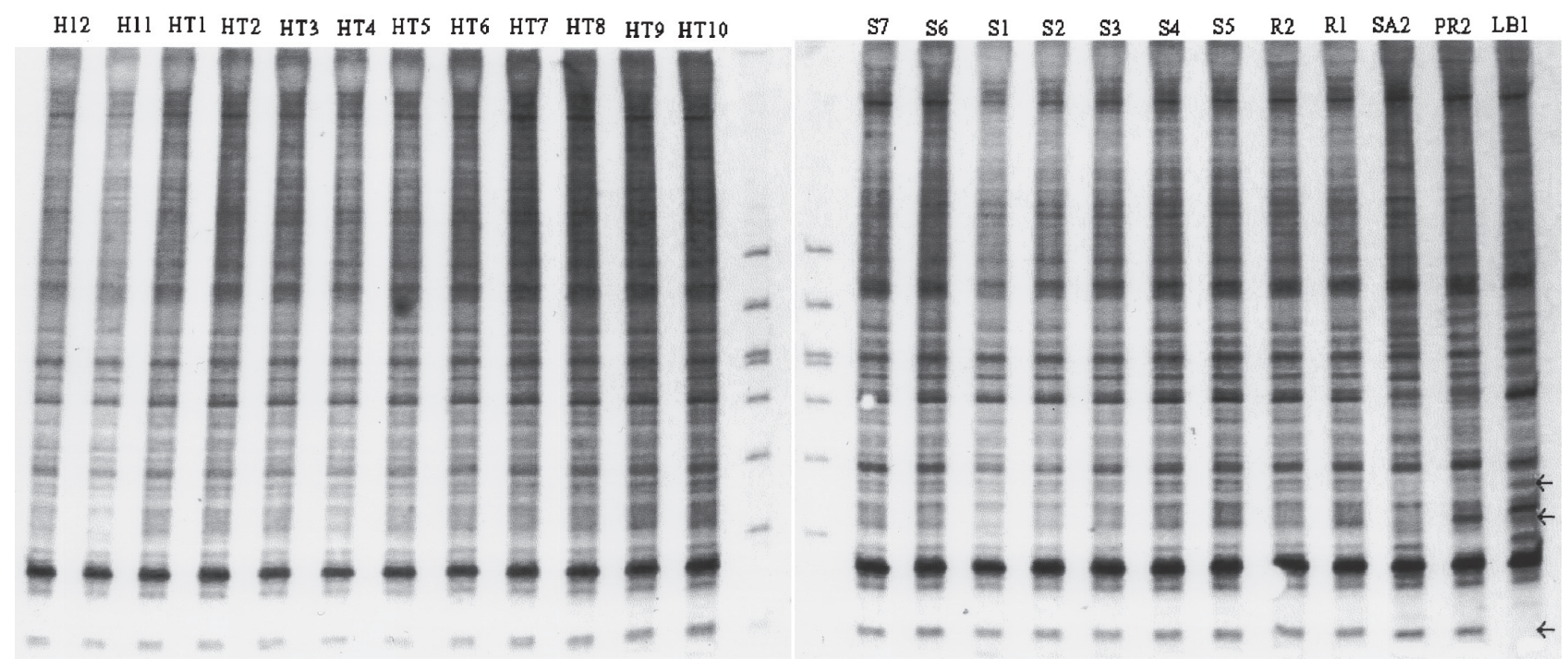

Fig. 1. DNA profiles of Cornus kousa cultivars 'Heart Throb' (H), 'Rosabella' (R), 'Satomi' (S), 'Samaritan' (SA), 'Little Beauty' (LB), and 'Christian Prince' (PR) generated by DNA amplification fingerprinting (DAF) using primer 5'-3' GTTACGCC (8.6I). Molecular marker bands correspond to (top to bottom) $1000,700,525,500,400,300,200$, and 100 base pairs. Each lane represents a different cultivar $\mathrm{H} 12, \mathrm{H} 11, \mathrm{H} 1, \mathrm{H} 2, \mathrm{H} 3, \mathrm{H} 4, \mathrm{H} 5, \mathrm{H} 6, \mathrm{H} 7, \mathrm{H} 8, \mathrm{H} 9, \mathrm{H} 10, \mathrm{~S} 7$, S6, S1, S2, S3, S4, S5, R2, R1, SA2, PR2, LB1. H11, H12, S6, S7, R2, R1, SA2, PR2, and LB1 were obtained from Oregon; all others were purchased in Tennessee. Note that all H, R, and S are monomorphic and that SA, LB and PR profiles contain polymorphic loci (arrowheads).

using unweighed pair group cluster analysis using arithmetic means (UPGMA). Node support (bootstrap values) was evaluated using WinBoot (Yap and Nelson, 1996).

\section{Results and Discussion}

Amplifications with each of the six DAF primers generated clear and reproducible DNA profiles for all individual plants of all cultivars (Fig. 1). In total, 173 bands were considered in the statistical analysis. The DNA profiles from all plants of 'Heart Throb' (except H2) and 'Rosabella' were identical regardless of nursery origin and primer used. The DAF products from one 'Satomi' plant (S7) was also identical to 'Heart Throb' and 'Rosabella' plants regard- less of primer used. All other 'Satomi' plants differed from 'Heart Throb' and 'Rosabella' plants by only one very thin, light-staining band when amplified by the primer 8.6J. The similarity indices generated using DAF data (Table 2) ranged between 0.99 and 1.00 (172 of 173 bands were monomorphic) for cultivars 'Heart Throb', 'Rosabella', and 'Satomi', supporting the contention that 'Heart Throb', 'Rosabella' and 'Satomi' are the same cultivar released under different names. An alternative hypothesis is that three discernible cultivars were originally released, but through confusion due to morphological similarities, one has become dominant in the trade as is the case with $C$. florida cultivars 'Barton' and 'Cloud Nine'(Windham and Trigiano, 1998).
DAF profiles generated from each specimen of 'Little Beauty' were identical as were those generated for plants of the cultivars 'Samaritan' and 'Christian Prince' (data not shown). Profiles between these cultivars were different from each other and from the profiles produced for 'Heart Throb', 'Rosabella', and 'Satomi'. Of the 173 bands, 82 were polymorphic and similarity indices were between 0.65 and 0.73. (Table 2). Unique DAF bands for 'Little Beauty', 'Samaritan', and 'Christian Prince' that could be used to identify these cultivars were resolved (arrows in Fig. 1). 'Little Beauty', 'Samaritan', and 'Christian Prince' are distinct and separate C. kousa cultivars (Fig. 2A)

ASAP analysis is a technique that detects

Table 2. Similarity indices for Cornus kousa cultivars 'Heart Throb', 'Satomi', 'Rosabella', 'Samaritan', 'Chrisitan Prince', and 'Little Beauty' based on NTSYSpc analysis of DNA Amplification Fingerprinting (DAF) data.

\begin{tabular}{|c|c|c|c|c|c|c|c|c|c|c|c|c|c|c|c|c|c|c|c|c|c|c|c|c|}
\hline & H12 & H11 & H1 & $\mathrm{H} 2$ & $\mathrm{H} 3$ & $\mathrm{H} 4$ & H5 & H6 & $\mathrm{H} 7$ & $\mathrm{H} 8$ & $\mathrm{H} 9$ & $\mathrm{H} 10$ & S7 & S6 & $\mathrm{S} 1$ & S2 & S3 & S4 & S5 & $\mathrm{R} 2$ & $\mathrm{R} 1$ & $\mathrm{SA} 2$ & PR2 & LB1 \\
\hline$\overline{\mathrm{H} 12}$ & 1.00 & & & & & & & & & & & & & & & & & & & & & & & \\
\hline H1 & 1.00 & 1.00 & 1.00 & & & & & & & & & & & & & & & & & & & & & \\
\hline H3 & 1.00 & 1.00 & 1.00 & 0.99 & 1.00 & & & & & & & & & & & & & & & & & & & \\
\hline $\mathrm{H} 4$ & 1.00 & 1.00 & 1.00 & 0.99 & 1.00 & 1.00 & & & & & & & & & & & & & & & & & & \\
\hline H5 & 1.00 & 1.00 & 1.00 & 0.99 & 1.00 & 1.00 & 1.00 & & & & & & & & & & & & & & & & & \\
\hline H6 & 1.00 & 1.00 & 1.00 & 0.99 & 1.00 & 1.00 & 1.00 & 1.00 & & & & & & & & & & & & & & & & \\
\hline H9 & 1.00 & 1.00 & 1.00 & 0.99 & 1.00 & 1.00 & 1.00 & 1.00 & 1.00 & 1.00 & 1.00 & & & & & & & & & & & & & \\
\hline H10 & 1.00 & 1.00 & 1.00 & 0.99 & 1.00 & 1.00 & 1.00 & 1.00 & 1.00 & 1.00 & 1.00 & 1.00 & & & & & & & & & & & & \\
\hline S7 & 1.00 & 1.00 & 1.00 & 0.99 & 1.00 & 1.00 & 1.00 & 1.00 & 1.00 & 1.00 & 1.00 & 1.00 & 1.00 & & & & & & & & & & & \\
\hline S6 & 0.99 & 0.99 & 0.99 & 0.98 & 0.99 & 0.99 & 0.99 & 0.99 & 0.99 & 0.99 & 0.99 & 0.99 & 0.99 & 1.00 & & & & & & & & & & \\
\hline S1 & 0.99 & 0.99 & 0.99 & 0.98 & 0.99 & 0.99 & 0.99 & 0.99 & 0.99 & 0.99 & 0.99 & 0.99 & 0.99 & 1.00 & 1.00 & & & & & & & & & \\
\hline S2 & 0.99 & 0.99 & 0.99 & 0.98 & 0.99 & 0.99 & 0.99 & 0.99 & 0.99 & 0.99 & 0.99 & 0.99 & 0.99 & 1.00 & 1.00 & 1.00 & & & & & & & & \\
\hline S3 & 0.99 & 0.99 & 0.99 & 0.98 & 0.99 & 0.99 & 0.99 & 0.99 & 0.99 & 0.99 & 0.99 & 0.99 & 0.99 & 1.00 & 1.00 & 1.00 & 1.00 & & & & & & & \\
\hline SA2 & 0.67 & 0.67 & 0.67 & 0.66 & 0.67 & 0.67 & 0.67 & 0.68 & 0.67 & 0.67 & 0.67 & 0.67 & 0.67 & 0.68 & 0.68 & 0.68 & 0.68 & 0.68 & 0.68 & 0.67 & 0.67 & 1.00 & & \\
\hline PR2 & 0.68 & 0.68 & 0.68 & 0.67 & 0.68 & 0.68 & 0.68 & 0.69 & 0.68 & 0.68 & 0.68 & 0.68 & 0.68 & 0.68 & 0.68 & 0.68 & 0.68 & 0.68 & 0.68 & 0.68 & 0.68 & 0.68 & 1.00 & \\
\hline LB1 & 0.73 & 0.73 & 0.73 & 0.72 & 0.73 & 0.73 & 0.73 & 0.73 & 0.73 & 0.73 & 0.73 & 0.73 & 0.73 & 0.72 & 0.72 & 0.72 & 0.72 & 0.72 & 0.72 & 0.73 & 0.73 & 0.65 & 0.65 & 1.00 \\
\hline
\end{tabular}




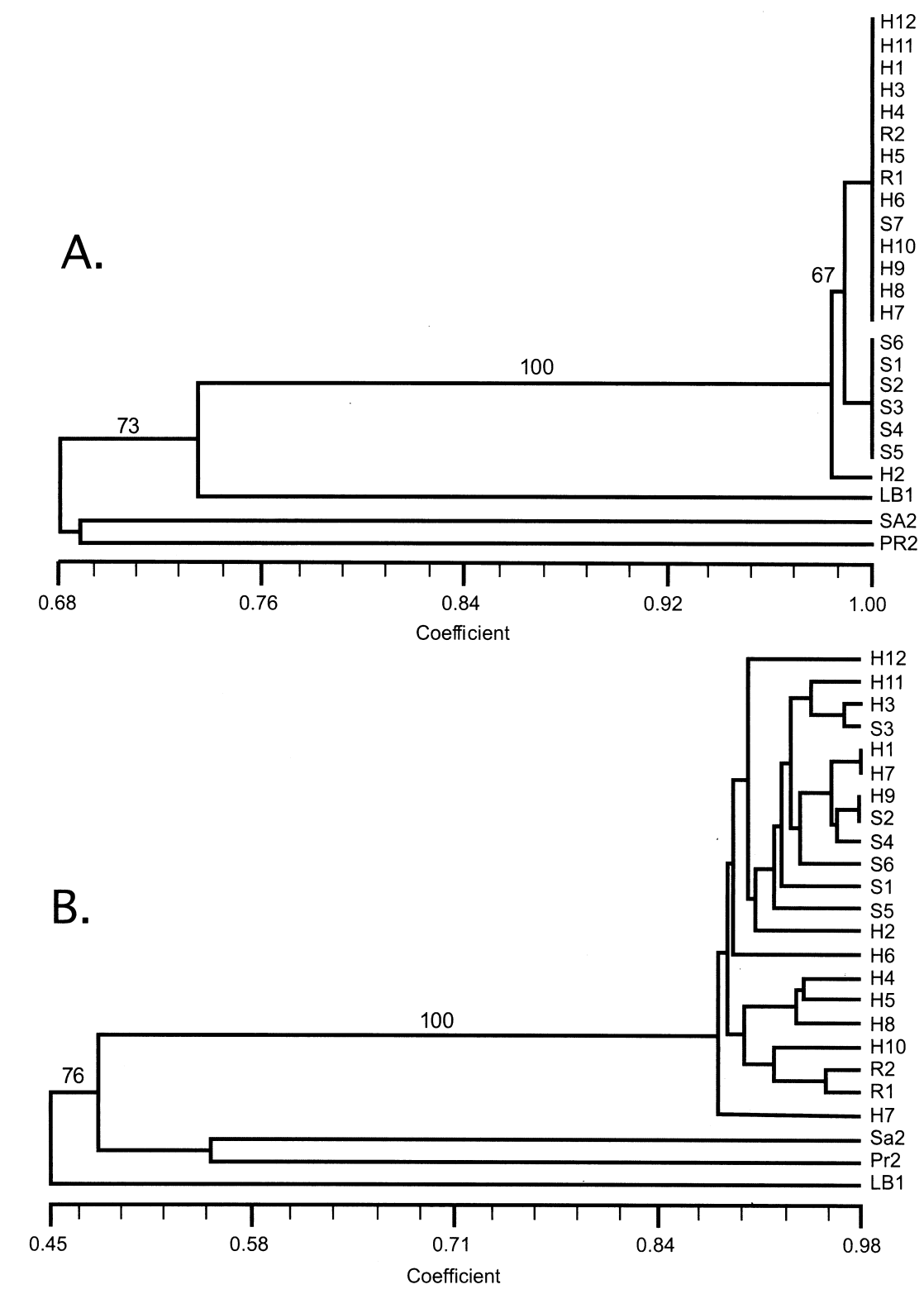

Fig. 2. (A) Cluster analysis of data generated by DNA amplification fingerprinting (DAF) of Cornus kousa cultivars 'Heart Throb' (H), 'Rosabella' (R), 'Satomi' (S), 'Samaritan' (SA), 'Little Beauty' (LB), and 'Christian Prince' (PR). See Table 1 for source nursery information. Bootstrap values $\leq 50$ are not shown. (B) Cluster analysis of data generated by arbitrary signatures from amplification profiles (ASAP) of Cornus kousa cultivars 'Heart Throb' (H), 'Rosabella' (R), 'Satomi' (S), 'Samaritan' (SA), 'Little Beauty' (LB), and 'Christian Prince' (PR). See Table 1 for source nursery information. Bootstrap values $\leq 50$ are not shown.

genomic differences more efficiently than DAF and has been used successfully to distinguish or identify very closely related individuals not resolved by DAF alone (Trigiano et al., 1998). In this study, 110 bands were generated with four $\mathrm{MH}$ primers using ASAP. Unique bands were not found that could identify either individual plants of 'Heart Throb', 'Rosabella', or 'Satomi' or distinguish these cultivars within the collection of plants used in the study. Of the 110 bands between these three cultivars, 23 were polymorphic. Analysis of the ASAP data set revealed that 'Heart Throb', 'Rosabella', and 'Satomi' had similarity indicies of at least 0.85 with most $\geq 0.93$ (Table 3 ) and remained tightly clustered together. The individual plants of the three cultivars from the various nurseries were scattered among numerous nodes, all of which had $<0.50$ support (Fig. 2B). Cluster analysis of ASAP data also supported the conclusion that 'Little Beauty', 'Samaritan', and 'Christian Prince' are distinct from the group of cultivars that contains 'Heart Throb', 'Rosabella', and 'Satomi' and that 'Little Beauty', 'Samaritan', and 'Christian Prince' are not closely related to each other (Fig. 2B)

In a similar study, DAF and ASAP profiles were used to determine that the white- bracted 'Barton' and 'Cloud Nine' flowering dogwood cultivars were genetically indistinguishable (Windham and Trigiano, 1998), and in the

Table 3. Similarity indices for Cornus kousa cultivars 'Heart Throb', 'Satomi', 'Rosabella', 'Samaritan', 'Chrisitan Prince', and 'Little Beauty' based on NTSYSpc analysis of Arbitrary Signatures from Amplification Profiles (ASAP) data.

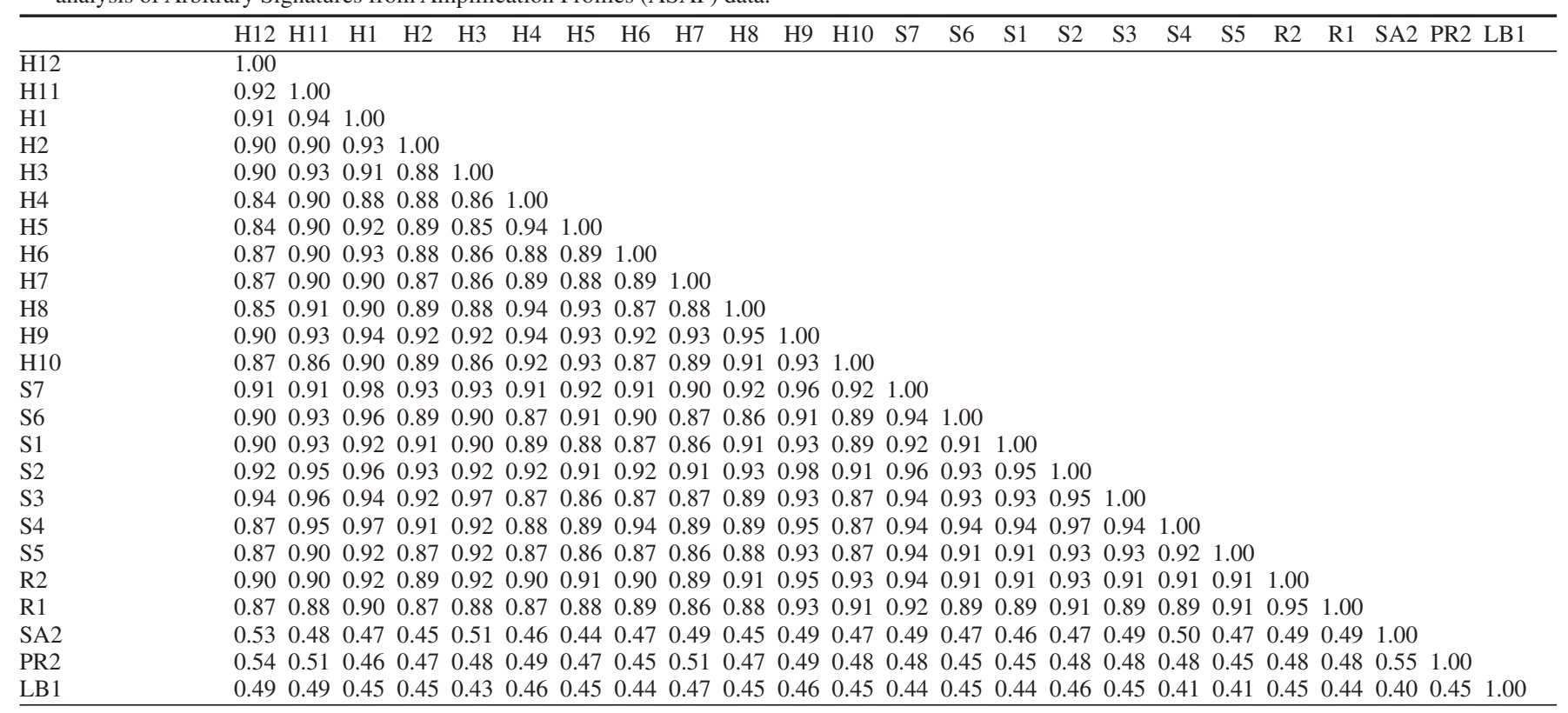


current study, ASAP also failed to cleanly resolve 'Heart Throb', 'Rosabella', and 'Satomi' groups (Fig. 2A and B). A possible explanation is that 'Heart Throb', 'Rosabella', and 'Satomi' lines did not originate from a single individual plant. Such is the case for

C. kousa var. chinensis 'Milky Way', which is derived from selections of as many as 15 open-pollinated seedlings that are collectively called 'Milky Way' (Dirr, 1998). Extensive phenotypic and genotypic variability among plants in this group is expected. Since C. kousa is self- sterile (Dirr, 1998) it is unlikely that 'Heart Throb', 'Rosabella', and 'Satomi' arose as selfed seedlings from the same mother plant. However, the high degree of similarity between separately named cultivars could be explained if 'Heart Throb', 'Rosabella', and 'Satomi' arose as full siblings. Eighty-seven percent of seedlings from the same open-pollinated C. florida mother tree were determined to be full siblings when the mother and pollen donor trees were in close proximity. Moreover, DAF profiles of the seedlings were very similar to each other (Ament et al., 2000).

Analysis of genomic DNA from ornamental plants has become an important tool for obtaining and protecting patent rights for cultivars and other plant materials. We anticipate that the use of these and more powerful emerging DNA profiling technologies will become rou- tine in the near future to separate and identify closely related phenotypes for the woody plant industry. We encourage nurserymen and plant breeders to characterize DNA of new materials before making patent applications and/or cultivar releases to avoid confusion between similar plants in the trade.

\section{Literature Cited}

Ament, M.H., M.T. Windham, and R.N. Trigiano. 2000. Determination of parentage of flowering dogwood (Cornus florida) seedlings using DNA amplification fingerprinting. J. Arboricult. 26:206-212.

Bassam, B.J.,G. Caetano-Anollés, and P.M. Gresshoff. 1991. Fast and sensitive silver staining of DNA in polyacrylamide gels. Anal. Biochem. 196:80-83.

Caetano-Anollés, G., B.J. Bassam, and P.M Gresshoff. 1991. DNA amplification fingerprinting using very short arbitrary oligonucleotide primers. Bio/Technology 9:553-557.

Caetano-Anollés, G. and P.M. Gresshoff. 1996. Generation of sequence signatures from DNA amplification fingerprints with mini-hairpin and microsatellite primers. Biotechniques 20:1044-1056

Caetano-Anollés, G. and R.N. Trigiano. 1997. Nucleic acid markers in agricultural biotechnology. AgBiotech. News Info. 9:235N-242N.

Dirr, M.A. 1998. Manual of woody landscape plants: Their identification, ornamental characteristics, culture, propagation and uses. $5^{\text {th }}$ ed. Stipes Publ.
L.L.C., Champaign, Ill.

Hagan, A.K., B. Hardin, C.H. Gilliam, G.J. Keever, J.D. Williams, and J.Eakes. 1998. Susceptibility of cultivars of several dogwood taxa to powdery mildew and spot anthracnose. J. Environ. Hort. 16:147-151.

Ranney, T.G., L.F. Grand, and J.L. Knighten. 1995. Susceptibility of Cornus kousa cultivars and hybrids to dogwood anthracnose and powdery mildew. J. Arboricult. 21:11-16.

Trigiano, R.N. and G. Caetano-Anollés. 1998. Laboratory exercises on DNA amplification fingerprinting for evaluating the molecular diversity of horticultural species. HortTechnology 8:413-423.

Trigiano, R.N., M.C. Scott, and G. Caetano-Anollés. 1998. Genetic signatures from amplification profiles characterize DNA mutation in somatic and radiation-induced sports of Chrysanthemum. J. Amer. Soc. Hort. Sci. 123:642-646.

Williams, J.K., A.R. Kubelik, K.J. Livak, J.A. Rafalski, and S.V. Tingey. 1990. DNA polymorphism amplified by arbitrary primers are useful as genetic markers. Nucleic Acid Res. 18:6531-6535.

Windham, M.T. and R.N. Trigiano. 1998. Are 'Barton' and 'Cloud 9' the same cultivar of Cornus florida? J. Environ. Hort. 16:163-166.

Yap, I.V. and R. J. Nelson. 1996. WinBoot: a program for performing bootstrap analysis of binary data to determine the confidence limits of UPGMAbased dendrograms. IRRI Discuss. Paper Ser. 14. Intl. Rice Res. Inst., Manila. 